\title{
Street Games of New York City
}

\section{John H. Chase}

To cite this article: John H. Chase (1905) Street Games of New York City, The Pedagogical Seminary, 12:4, 503-504, DOI: 10.1080/08919402.1905.10534676

To link to this article: http://dx.doi.org/10.1080/08919402.1905.10534676

曲 Published online: 30 Aug 2012.

Submit your article to this journal 저

Џll Article views: 4

Q View related articles $\asymp$

4 Citing articles: 4 View citing articles 
By John H. Chase,

Head Worker, Maxwell House, Brooklyn, N. Y.

Children have been asked what games they liked the best, and from these lists the most popular games have been tabulated. Such lists have been made for Brooklyn children, and for Worcester children.

The trouble with this method is that the most recent games played are apt to be recorded by children as the best, gambling games-like craps-are rarely mentioned, and finally children often record games which they enjoy, but rarely play.

Realizing these defects, and desiring to obtain an accurate list of the most popular out-door games of New York City, I followed the plan, for two years, of walking through the crowded tenement house streets and tabulating (I) the different games being played, (2) the number of children playing each, (3) the amount of seeming interest, (4) the date. The same streets were generally covered each day, but this was varied occasionally to see if different regions were doing the same thing. As a rule, with some variations, the great mass of tenement house children played the same games at the same time the city over. And the ten most popular games during the season when I could watch them, were:

I. Playing with fire-bonfires, fires in buckets, etc.

II. Craps - a gambling game with dice.

III. Marbles-always "for keeps," and a simpler game than in the country; several simple varieties.

IV. Potsie-a primitive kind of hop scotch.

V. Leap frog-over milk cans and fire pumps, as well as over boys. Commonest contest to see who can leap the farthest before clearing the obstacle. Many varieties-"head and footer," Spanish fly, etc.

VI. Jumping rope.

VII. Baseball. Probably should be nearer head of the list, but my observations did not include the summer.

VIII. Cat. It is probably also played in the summer. A short stick is pointed at one end and placed on the street. The point is tapped with a longer stick or bat. When the short stick bounds into the air it is hit down the street, and the other boy throws it back as near the starting point as possible. 
There are three ways of scoring, according to which variety of game is being played.

IX. Buttons. Boys throw, or slide, buttons in turn, from street curb toward a wall. The boy coming the nearest throws all the buttons up into the air. They fall in a shower and the ones which land "heads up" are his. Then the boy who came second closest throws the rest up, and keeps those that land "heads up," etc. The same game is played for other things. Cigarette pictures are played for in this way during January; pennies and almost anything flat at different seasons.

$X$. Tops. They are generally put in a ring, and the game is to split your opponent's top. You may have a poor top for splitting purposes and a good one for spinning.

The dates for different games are as follows :

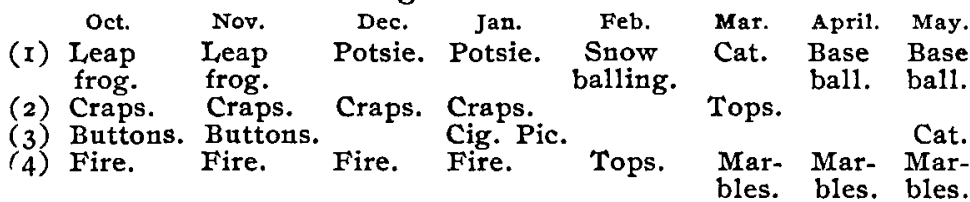

\section{Conclusion.}

I. These ten games are unlike any lists made from the answers of children.

2. The table shows the fire instinct to be very strong.

3. The gambling instinct is very strong.

4. Three popular games are generally going on at the same time.

5. The running games such as tag, prisoner's base, etc., are replaced by cramped games such as leap frog, hop scotch, etc. 